\title{
PENERAPAN TEKNIK RELAKSASI NAFAS DALAM TERHADAP PENURUNAN INTENSITAS NYERI PADA ASUHAN KEPERAWATAN PASIEN GASTRITIS
}

\author{
Tuti Elyta ${ }^{1}$, Miming Oxyandi ${ }^{2}$, Reginta Ayu Cahyani ${ }^{3}$ \\ Akademi Keperawatan Pembina Palembang ${ }^{1,3}$ \\ Prodi DIII Keperawatan, STIKES ‘Aisyiyah Palembang ${ }^{2}$ \\ akperpembina5@gmail.com ${ }^{1}$ \\ miming@stikes-aisyiyah-palembang.ac.id ${ }^{2}$ \\ regintaayucahyani@gmail.com ${ }^{3}$
}

\begin{abstract}
ABSTRAK
Gastritis termasuk proses inflamasi atau gangguan kesehatan yang disebabkan oleh faktor iritasi dan infeksi pada mukosa dan submukosa lambung. Penyakit Gastritis biasa dikenal dengan penyakit maag. Tujuan penelitian ini Memperoleh pengalaman dan pengetahuan secara nyata serta dapat mendokumentasikan dalam Penerapan Teknik Relaksasi Nafas Dalam terhadap Intensitas Nyeri pada Asuhan Keperawatan Gastritis. Metode penelitian ini adalah Jenis Karya tulis ilmiah ini menggunakan metode deskritif dengan pendekatan studi kasus untuk mengeksplorasi masalah Asuhan Keperawatan pada dua pasien dengan Gastritis. Asuhan keperawatan dilakukan pada dua pasien yang dilakukan pada tanggal 16-18 Juni 2021. Dari hasil asuhan keperawatan pada Tn"H" dan Ny"S" dengan diagnosa pertama yaitu Nyeri Akut berhubungan dengan agen pencendera fisiologis (inflamasi pada mukosa lambung). Hasil evaluasi pada pasien pertama Tn " $H$ " didapatkan pasien tidak merasakan nyeri lagi, sebelum dilakukan Teknik relaksasi nafas dalam skala nyeri 5 (sedang), masalah nyeri teratasi, dan intervensi di hentikan. Untuk evaluasi yang didapat pasien kedua $\mathrm{Ny}$ "S" didapatkan skala 2 (Ringan), sebelum dilakukan Teknik relaksasi nafas dalam skala nyeri 6 (sedang), masalah nyeri teratasi Sebagian, dan intervensi dilanjutkan oleh perawat ruangan. Berdasarkan kesimpulan, atatan perkembangan kepada kedua pasien penerapan teknik relaksasi nafas dalam untuk menurunkan intensitas nyeri. Hasil evaluasi keperawatan pada $\mathrm{Tn}$ " $\mathrm{H}$ " masalah teratasi sedangkan pada Ny "S" masalah teratasi sebagian.
\end{abstract}

\section{Kata Kunci : Asuhan Keperawatan Gastritis, Teknik Relaksasi Nafas Dalam, Nyeri}

\begin{abstract}
Gastritis includes inflammatory processes or health problems caused by irritants and infections of the mucosa and submucosal stomach. Gastritis is commonly known as ulcer disease. The purpose of this study is to gain real experience and knowledge and can document in the Application of Deep Breath Relaxation Techniques to Pain Intensity in Gastritis Nursing Care.. This type of scientific paper uses a deskritive method with a case study approach to explore the problem of Nursing Care in two patients with Gastritis. Nursing care was carried out on two patients conducted on June 16-18, 2021. From the results of nursing care in Mr. "H" and Mrs"S" with the first diagnosis of Acute Pain associated with physiological weighing agents (inflammation of the gastric mucosa). The results of the evaluation in the first patient Mr."H" obtained the patient did not feel pain anymore, before the breathing relaxation technique on a pain scale of 5 (moderate), pain problems resolved, and intervention stopped. For the evaluation obtained by the second patient Mrs"S" obtained a scale of 2 (Mild), before the breathing relaxation technique on the pain scale 6 (moderate), pain problems resolved partially, and intervention continued by the room nurse. Based on the conclusion, the atatan development to both patients application of deep breath relaxation techniques to reduce the intensity of pain. The results of nursing evaluation on $\mathrm{Mr}$. "H" the problem is resolved while in Mrs. "S" the problem is partially resolved.
\end{abstract}

Keywords: Gastritis Nursing Care, Deep Breath Relaxation Techniques, Pain

Volume XI No. 2 Desember $2021 \mathrm{Hal}$ - 136 


\section{PENDAHULUAN}

Penyakit pada sistem pencernaan adalah penyebab paling umum terjadinya nyeri. Salah satunya penyakit gastritis atau yang biasanya di kenal dengan maag. Gastritis merupakan peradangan yang mengenai mukosa lambung (Nurhanifah, Afni, \& Rahmawati, 2018).

Gastritis akan sangat mengganggu aktivitas sehari-hari, baik bagi remaja maupun orang dewasa. Gastritis merupakan peradangan (inflamasi) dari mukosa lambung yang disebabkan oleh faktor iritasi dan infeksi. Gastritis dapat terjadi tiba-tiba (gastritis akut) atau secara bertahap (gastritis kronis). Kebanyakan kasus gastritis tidak secara permanen merusak 2 lapisan perut tetapi seseorang yang menderita gastritis sering mengalami serangan kekambuhan yang mengakibatkan nyeri di ulu hati (Saydam, 2017).

Badan Penelitian kesehatan dunia World Health Organization (WHO) mengadakan tinjauan terhadap beberapa negeri dunia dan mendapatkan hasil dari angka persentase kejadian gastritis Menurut Wort Health Organization (WHO) mendapatkan hasil dari angka persentase gastritis di dunia, diantaranya Inggris 22\%, China 31\%, Jepang 14,5\%, Kanada 35\%, dan Prancis 29,5\%. Insiden terjadinya gastritis di Asia Tengggara sekitar 583.635 dari jumlah penduduk setiap tahunnya (WHO, 2018).

Kejadian gastritis di Indonesia Angka kejadian gastritis cukup tinggi dengan prevalensi 274.396 kasus dari 238.452.952 jiwa penduduk. Berdasarkan Data Kesehatan Indonesia terdapat sepuluh penyakit terbanyak di rumah sakit di Indonesia, pada pasien rawat inap gastritis berada pada posisi keenam dengan jumlah kasus sebesar 33.580 kasus yang $60.86 \%$ terjadi pada perempuan. Pada pasien rawat jalan gastritis berada pada posisi ketujuh dengan jumlah kasus 201.083 kasus yang $77,74 \%$ terjadi pada perempuan (Kementrian Kesehatan RI, 2018). Sedangkan dari data dinas kota Palembang didapatkan angka kejadian gastritis pada tahun 2016 sebanyak 48.162 orang, tahun 2017 sebanyak 49.115 orang dan tahun 2018 sebanyak 54.159 orang (Dinas Kesehatan Kota Palembang, 2019). Berdasarkan data Medikal Record ditempat penelitian di ruangan Penyakit Dalam angka kejadian Gastritis tiap tahunnya mengalami penurunan. Pada tahun 2015 sebanyak 179 orang, tahun 2016 sebanyak 173 orang, tahun 2017 sebanyak 159 orang, tahun 2018 sebanyak 102 orang, Tahun 2019 sebanyak 64 orang dan tahun 2020 sebanyak 25 orang.

Penyakit Gastritis biasa dikenal dengan penyakit maag. Gastritis ini merupakan suatu peradangan atau pendarahan pada mukosa lambung yang disebabkan oleh faktor iritasi, infeksi, dan ketidakteraturan dalam pola makan, misalnya telat makan, makan terlalu banyak, makan cepat, makan makanan yang terlalu banyak bumbu pedas, mengkonsumsi protein tinggi, kebiasaan mengkonsumsi makan-makanan pedas, dan minum kopi terlalu berlebihan (Huzaifah, 2017). Gastritis termasuk proses inflamasi atau gangguan kesehatan yang disebabkan oleh faktor iritasi dan infeksi pada mukosa dan submukosa lambung. Penyakit Gastritis dapat menyerang seluruh lapisan masyarakat dari semua tingkat usia maupun jenis kelamin, akan tetapi dari beberapa survei menunjukkan bahwa gastritis paling sering menyerang usia produktif (Tussakinah et al, 2018).

Salah satu manifestasi klinis yang terjadi pada pasien Gastritis adalah nyeri. Nyeri yang dirasakan adalah nyeri ulu hati atau nyeri epigastrium. Secara umum tanda dan gejala yang sering terjadi pada pasien tercermin dari perilaku pasien yang mengalami nyeri misalnya suara (menangis, merintih, menghembuskan nafas), ekspresi wajah (meringis, menggigit bibir), pergerakan tubuh (gelisah, otot tegang, mondar-mandir, dll), interaksi social (Supetran, 2018).

Penelitian Utami \& Kartika (2018), Hasil penelitiannya menunjukkan bahwa penggunaan tehnik relaksasi nafas dalam sangat efektif dalam membantu meringankan nyeri yang dialami pasien gastritis, oleh karena itu memudahkan dalam proses penyembuhan. 
Sedangkan penelitian Erni, Zainal \& Titah (2020). Dari hasil meriview jurnal tersebut menunjukkan bahwa setelah dilakukannya relaksasi menunjukkan adanya kecenderungan penurunan jumlah responden yang mengalami nyeri. Hal ini dikarenakan pemberian tehnik relaksasi dapat memberikan perubahan signifikan pada penurunan rasa nyeri, penggunaan relaksasi juga dirasakan efektif.

Salah satu terapi non-farmakologi yang dapat diberikan pada penderita yang mengalami nyeri pada gastritis adalah terapi komplementer. Beberapa tindakan mandiri yang dapat di laksanakan perawat untuk membantu klien yaitu dengan menggunakan Manajemen Nyeri untuk menghilangkan atau mengurangi nyeri dan meningkatkan rasa nyaman. Salah satu Menggunakan komunikasi terapeutik untuk mengetahui pengalaman nyeri pada pasien yaitu dengan menggunakan teknik relaksasi nafas dalam (Indayani, 2018).

Menurut Aningsih (2018), menjelaskan bahwa teknik relaksasi nafas dalam adalah bernafas dengan perlahan menggunakan diafragma, sehingga memungkinkan abdomen terangkat perlahan dan dada mengembang penuh. Dalam teknik ini merupakan suatu bentuk asuhan keperawatan, bagaimana perawat mengajarkan cara melakukan teknik relaksasi nafas salam, nafas lambat (menahan inspirasi secara maksimal) dan bagaimana menghembuskan nafas secara perlahan, selain dapat menurunkan intensitas nyeri, teknik relaksasi nafas dalam juga dapat meningkatkan ventilasi paru dan meningkatkan oksigenasi darah.

Berdasarkan uraian diatas maka penulis tertarik mengambil kasus karya tulis ilmiah dengan judul "Asuhan Keperawatan Pada Klien Gastritis Dengan Masalah Keperawatan Nyeri dengan teknik relaksasi nafas dalam".

\section{METODE PENELITIAN}

Jenis Penelitian pada karya tulis ilmiah ini menggunakan metode deskriptif dengan pendekatan studi kasus. Metode penelitian deskriptif merupakan suatu metode penelitian yang dilakukan dengan tujuan utama untuk membuat gambaran tentang suatu keadaan secara objektif dengan pendekatan studi kasus (Notoatmodjo, 2014).

Subjek dalam studi kasus ini adalah pasien Gastritis, adapun sampel penelitian yang diteliti berjumlah dua pasien dengan pasien pertama berinisial Tn.H yang berusia 58 tahun dan pasien kedua dengan inisial Ny.S yang berusia 46 tahun, dengan tujuan dapat membandingkan masalah keperawatan Gastritis.

Asuhan keperawatan dilakukan pada dua pasien diruang penyakit dalam disalah satu rumah sakit umum daerah Palembang, Asuhan ini dilakukan dimulai dari kegiatan penyusunan proposal, pengumpulan data, dilanjutkan dengan pengolahan hasil serta penulisan laporan penelitian dari bulan Maret s/d Juni 2021. Sedangkan proses pengambilan asuhan keperawatan dari tanggal 15 s/d 18 Juni 2021.

Prosedur penelitian ini dilakukan setelah mendapat persetujuan dari pihak rumah sakit lalu mengajukan persetujuan penelitian (informed consent) kepada kedua subjek dengan memperhatikan prinsip etika yang meliputi hak untuk self determination; hak terhadap privacy dan dignity; hak terhadap anonymity dan confidentiality. Lalu dilanjutkan dengan proses asuhan keperawatan pertama melakukan pengkajian pada kedua pasien terlebih dahulu, kemudian dilanjutkan dengan penentuan diagnosa dan penyusunan rencana keperawatan yang akan dilakukan dan terakhir melakukan evaluasi keperawatan dari tindakan yang diterapkan dengan format SOAP hingga proses asuhan keperawatan berakhir.

Metode pengumpulan data studi kasus ini mengunakan teknik :
a. Wawancara
b. Observasi
c. Pemeriksaan fisik (dengan pendekatan IPPA : inspeksi, palpasi, perkusi, auskultasi) pada sistem tubuh Pasien.
d. Studi dokumentasi (hasil dari pemerikasaan diagnostik)

Alat atau instrumen pengumpulan data menggunakan format pengkajian dengan pendekatan pemeriksaan fisik head to toe 
menggunakan format pengkajian SDKI serta format penentuan rencana SIKI dan SLKI. Analisa data yang digunakan dalam studi kasus ini adalah analisis deskriptif yang disajikan secara tekstular/narasi. Analisa data dilakukan sejak peneliti dilapangan, mengumpulkan data sampai data terkumpul semua, Analisa data dengan cara mengemukakan fakta, selanjutnya membandingkan dengan teori yang ada dan selanjutnya dituangkan dalam opini pembahasan. Teknik analisis yang digunakan dengan cara menarasikan jawaban-jawaban dari penulisan yang diperoleh dari hasil interpretasi wawancara mendalam yang dilakukan untuk menjawab rumusan masalah penulisan. Teknik analisis digunakan dengan cara observasi oleh penulis dan studi dokumentasi yang menghasilkan data untuk selanjutnya dinterpretasikan dan dibandingkan teori yang ada sebagai bahan untuk memberikan rekomendasi dalam intervensi tersebut.

\section{HASIL DAN PEMBAHASAN}

Setelah memberikan asuhan keperawatan pada pasien Gastritis pada Tn.H dan Ny.S dilakukan pada tanggal 15-18 Juni 2021. Proses keperawatan mulai dari pengkajian, penentuan diagnosis keperawatan, perencanaan, implementasi dan evaluasi.

\section{Pengkajian}

Berdasarkan hasil pengkajian menggunakan pendekatan pemeriksaan fisik head to toe, didapatkan hasil pengkajian sebagai berikut:

\section{Kasus 1 (Tn. H)}

Pengkajian dilakukan pada tanggal 16 Juni 2021. Hasil pengkajian didapatkan Tn. H alasan datang ke Rumah Sakit karena mengeluh nyeri di ulu hati, mual muntah, nafsu makan berkurang sudah 3 hari yang lalu. Pasien sebelumnya ada riwayat penyakit Diabetes mellitus. Hasil pemeriksaan fisik diperoleh data subjektif; Pasien mengatakan nyeri di ulu hati, adanya mual muntah dan nafsu makan berkurang. Pasien mengatakan memiliki kebiasaan minum kopi dan jarang sarapan pagi. Pasien hanya bisa makan berbentuk bubur saring yang diberikan dari rumah sakit, saat makan pun pasien merasa mual dan muntah. Pasien mengatakan juga susah untuk tidur dikarenakan nyeri yang dirasakan hilang timbul saat malam hari. Sedangkan data objektifnya; GCS 15 (Composmentis), Skala nyeri 5 (sedang), keadaan umum pasien lemah, adanya nyeri tekan di abdomen, pasien tampak meringis kesakitan, Bising Usus 10x/menit, Makanan pasien tampak berbentuk bubur saring, dan pasien tampak mengantuk serta bawah mata pasien tampak menghitam Rentang gerak terbatas, Kekuatan otot skala 5/5, TD: 100/60 mmHg, Nadi: 84 x/menit, RR: 20 x/menit, T: $36,6 \mathrm{C}$.

\section{Kasus 2 (Ny. S)}

Pengkajian dilakukan pada tanggal 16 Juni 2021. Hasil pengkajian didapatkan Ny. S alasan datang ke Rumah Sakit karena mengeluh nyeri di ulu hati memberat, mual muntah, nafsu makan berkurang, demam sudah 1 hari yang lalu. Pasien sebelumnya ada riwayat penyakit Hipertensi. Hasil pemeriksaan fisik diperoleh data subjektif; Pasien mengatakan nyeri di ulu hati, adanya mual muntah, nafsu makan berkurang dan demam. Pasien mengatakan memiliki kebiasaan suka makan makanan yang pedas dan asam. Pasien hanya bisa makan berbentuk bubur saring yang diberikan dari rumah sakit, saat makan pun pasien merasa mual dan muntah. Pasien mengatakan juga badannya terasa panas. Sedangkan data objektifnya; GCS 15 (Composmentis), Skala nyeri 6 (sedang), keadaan umum

Pengkajian adalah nilai dasar dari proses keperawatan yang bertujuan untuk mengumpulkan informasi atau data tentang pasien, agar dapat mengidentifikasi, mengenali masalah-masalah, kebutuhan kesehatan dan keperawatan pasien baik fsik, mental, sosial dan lingkungan (Effendi, 2015).

Hasil pengkajian dari Tn. $\mathrm{H}$ dan Ny. S nyeri di ulu hati, adanya mual muntah dan nafsu makan berkurang. Berdasarkan hasil pemeriksaan laboratorium pada kedua pasien, dapat dilihat pada tabel 1 sebagai berikut. 
Tabel 1

Hasil Pemeriksaan Laboratorium

\begin{tabular}{clccc}
\hline No & Pemeriksaan Diagnostik & Kasus 1 (Tn.H) & Kasus 2 (Ny. S) & Nilai Normal \\
\hline 1. & Hemoglobin & 5.1 & 13.1 & $14-16$ \\
\hline 2. & Leokosit & 61.5 & 11.3 & $5-10$ \\
\hline 3. & Trombosit & 92 & 331 & $150-400$ \\
\hline 4. & Hematokrit & 14 & 39 & $40-52$ \\
\hline 5. & Eosinofil & 1 & 1 & $1-3$ \\
\hline 6. & Basofil & 0 & 0 & $0-1$ \\
\hline 7. & Neutrofil Batang & 2 & 2 & $2-6$ \\
\hline 8. & Neutrofil Segmen & 57 & 55 & $50-70$ \\
\hline 9. & Limfosit & 30 & 5 & $20-40$ \\
\hline 10 & Monosit & 6 & $5-8$ \\
\hline
\end{tabular}

Pada pengkajian keluhan utama saat dikaji, kedua pasien mengeluh nyeri di ulu hati. Menurut (S.C. keadaan umum pasien lemah, adanya nyeri tekan di abdomen, pasien tampak meringis kesakitan, Bising Usus 11x/menit, Makanan pasien tampak berbentuk bubur saring, dan badan pasien teraba panas. Rentang gerak terbatas, Kekuatan otot skala 5/5, TD: 180/90 mmHg, Nadi: 80 x/menit, RR: 24 x/menit, $\mathrm{T}: 37,7 \mathrm{C}$.

Smeltzer (2013) Nyeri akut ialah nyeri yang berlangsung umumnya kurang dari enam bulan dan biasanya kurang dari satu bulan. Nyeri akut merupakan pengalaman sensorik atau emosional yang berkaitan dengan kerusakan jaringan atau fungsional, dengan onset mendadak atau lambat dan berintensitas ringan hingga berat yang berlangsung kurang dari 3 bulan. (PPNI, 2016).

Menurut penelitian Utami \& Kartika (2018) salah satu manifestasi klinis yang terjadi pada pasien gastritis adalah nyeri serta nampak pada perilaku pasien, misalnya suara (merintih, menangis, dan menghela nafas berlebihan), ekspresi wajah meringis, serta pergerakan tubuh seperti gelisah, kejang otot, serta berjalan di tempat

Berdasarkan asumsi peneliti terdapat kesamaan bahwa pasien sebelumnya memiliki kebiasaan minum kopi, makan makanan pedas dan asam serta jarang sarapan pagi yang menjadi faktor resiko terjadinya gastritis. Hasil pengkajian dari Tn. H dan Ny. S nyeri di ulu hati, adanya mual dan muntah, berkirangnya nafsu makan, susah tidur karna nyeri yang dirasakan serta adanya demam. sehingga kedua pasien merasakan nyeri yang hilang timbul pada ulu hatinya sehingga pasien membutuhkan Teknik relaksasi nafas dalam secara rutin untuk meredakan dan meghilangkan rasa nyeri sehingga pasien melakukan aktivitas hidup harian (Activities of Daily living atau ADL) dapat terjadi peningkatan kemampuan dalam melakukan aktivitas hidup hariannya.

Berdasarkan asumsi peneliti terdapat kesamaan bahwa pasien sebelumnya memiliki kebiasaan minum kopi, makan makanan pedas dan asam serta jarang sarapan pagi yang menjadi faktor resiko terjadinya gastritis. Hasil pengkajian dari Tn. H dan Ny. S nyeri di ulu hati, adanya mual dan muntah, berkirangnya nafsu makan, susah tidur karna nyeri yang dirasakan serta adanya demam. sehingga kedua pasien merasakan nyeri yang hilang timbul pada ulu hatinya sehingga pasien membutuhkan Teknik relaksasi nafas dalam secara rutin untuk meredakan dan meghilangkan rasa nyeri sehingga pasien melakukan aktivitas hidup harian (Activities of Daily living atau ADL) dapat 
terjadi peningkatan kemampuan dalam melakukan aktivitas hidup hariannya.

\section{Diagnosa Keperawatan}

Diagnosis Keperawatan merupakan suatu penilaian klinis mengenai respons klien terhadap masalah kesehatan atau proses kehidupan yang dialaminya baik yang berlangsung actual maupun potensial. Diagnosis keperawatan bertujuan untuk mengidentifikasi respons klien individu, keluarga dan komunitas terhadap situasi yang nerkaitan dengan kesehatan (Tim Pokja SDKI DPP PPNI, 2017).

Analisa data dari hasil pengkajian merupakan rumusan dalam menentukan diagnosa keperawatan kepada kedua pasien pada kenyataan untuk kasus Tn. $\mathrm{H}$ dan $\mathrm{Ny}$. S. Peneliti menemukan 6 diagnosa, diantaranya 4 diagnosa yang sama dan 2 diagnosa yang berbeda, berikut diagnosa keperawatan yang ditemukan. berbeda, berikut diagnosa keperawatan yang ditemukan.

Tabel 2.

Diagnosa Keperawatan

\begin{tabular}{cllcl}
\hline \multicolumn{6}{c}{ MASALAH KEPERAWATAN } \\
\hline No & \multicolumn{1}{c}{ Pasien Tn. H } & No & \multicolumn{1}{c}{ Pasien Ny. S } \\
\hline 1. & $\begin{array}{l}\text { Nyeri akut berhubungan dengan agen } \\
\text { pencendera fisiologis (inflamasi pada } \\
\text { mukosa lambung) (D.0077) }\end{array}$ & 1 & $\begin{array}{l}\text { Nyeri akut berhubungan dengan agen } \\
\text { pencendera fisiologis (inflamasi pada } \\
\text { mukosa lambung) (D.0077) }\end{array}$ \\
\hline 2. & $\begin{array}{l}\text { Gangguan Pola Tidur berhubungan dengan } \\
\text { kurang Kontrol tidur (mengeluh sulit tidur } \\
\text { karna nyeri) (D.0055) }\end{array}$ & 2 & $\begin{array}{l}\text { Termogulasi tidak efektif berhubungan } \\
\text { dengan stimulasi pusat termogulasi } \\
\text { (inflamasi). (D.0149) }\end{array}$ \\
\hline 3. & $\begin{array}{l}\text { Defisit Nutrisi berhubungan dengan } \\
\text { ketidakmampuan mencerna makanan. } \\
\text { (D.0019) }\end{array}$ & $\begin{array}{l}\text { Defisit Nutrisi berhubungan dengan } \\
\text { ketidakmampuan mencerna makanan. } \\
\text { (D.0019) }\end{array}$ \\
\hline
\end{tabular}

Pada kenyataan untuk kasus Tn. H dan Ny. S menemukan 6 diagnosa, diantaranya 4 diagnosa yang sama dan 2 diagnosis yang berbeda. Pada diagnosis keperawatan secara teori penulis mendapatkan 4 diagnosis dari refrensi SDKI yaitu sebagai berikut : Nyeri akut berhubungan dengan agen pencendera fisiologis (inflamasi pada mukosa lambung) (D.0077), Gangguan Pola Tidur berhubungan dengan kurang Kontrol tidur (mengeluh sulit tidur karna nyeri) (D.0055), Termogulasi tidak efektif berhubungan dengan stimulasi pusat termogulasi (inflamasi). (D.0149), Defisit Nutrisi berhubungan dengan ketidakmampuan mencerna makanan. (D.0019). (SDKI, 2017).

Pada pasien satu dan pasien dua memiliki perbedaan, karena pada saat pengkajian tidak ada data yang mendukung untuk merumuskan diagnosis seluruhnya, keenam diagnosis yang diangkat memang telah sesuai dengan hasil yang didapatkan saat pengkajian, baik secara subjektif maupun objektif dan keempat diagnosis tersebut sesuai dengan kriteria yang ada dalam perumusan diagnosis. Salah satu diagnosis keperawatan yang muncul yaitu Nyeri akut berhubungan dengan agen pencendera fisiologis (inflamasi pada mukosa lambung) (D.0077). pada dua pasien studi kasus ini pelaksanaan keperawatan hanya berfokus pada satu masalah keperawatan yaitu masalah nyeri akut dan berfokus pada tindakan Teknik relaksasi nafas dalam.

Sesuai rujukan teori SDKI (2017) bahwa adanya gejala dan tanda mayor dan minor dengan diagnosis nyeri akut yaitu gejala dan tanda mayor subjektif : mengeluh nyeri, objektif : tampak meringis, bersikap protektif (mis. Waspada, posisi menghindari nyeri), gelisah, frekuensi nadi meningkat, dan sulit tidur. Sedangkan gejala dan tanda minor subjektif : tidak tersedia, objektif : tekanan darah meningkat, pola nafas berubah, nafsu 
makan berubah, proses berfikir terganggu, menarik diri, berfokus pada diri sendiri, dan diaforresis.

Berdasarkan asumsi peneliti bahwa diagnosis yang muncul pada pasien satu dan dua yaitu terdapat perbedaan, karena pada saat pengkajian tidak ada data yang mendukung untuk merumuskan diagnosis seluruhnya. Pada pasien satu muncul tiga diagnosa di mana sesuai dengan data objektif dan subjektif. Sedangkan pada pasien dua terdapat 3 diagnosa. pada dua pasien studi kasus ini pelaksanaan keperawatan hanya berfokus pada satu masalah keperawatan yaitu nyeri akut dan berfokus pada tindakan Teknik relaksasi nafas dalam. Hal ini karena pasien merasakan nyeri di ulu sehingga membutuhkan Teknik relaksasi nafas dalam secara rutin untuk meredakan dan menghilangkan rasa nyeri sehingga pasien melakukan aktivitas hidup harian (Activities of Daily living atau ADL) dapat terjadi peningkatan kemampuan dalam melakukan aktivitas hidup hariannya.

\section{Intervensi Keperawatan}

Intervensi keperawatan pada studi kasus ini yang berfokus baik pada kasus 1 maupun kasus 2 pada diagnosis nyeri akut memiliki tujuan setelah dilakukan tindakan keperawatan selama 3×24 jam Maka tingkat nyeri menurun dengan kriteria hasil : Keluhan nyeri menurun, Keluhan nyeri menurun, Meringis menurun, Sikap protektif menurun, dan Gelisah menurun Intervensi yang ditentukan pada kasus 1 dan kasus 2 yaitu yang direncanakan yaitu Identifikasi lokasi, karakteristik, durasi, frekuensi, kualitas dan intensitas nyeri, identifikasi skala nyeri, berikan teknik non-farmakologi untuk mengurangi rasa nyeri yaitu teknik relaksasi nafas dalam, jelaskan penyebab, periode, dan pemicu nyeri, anjurkan mengambil posisi nyaman, demonstrasikan dan latih teknik relaksasi, dan kolaborasi pemberian analgetik.

Intervensi keperawatan adalah segala treatment yang dikerjakan oleh perawat yang didasarkan pada pengetahuan dan penilaian klinis untuk mencapai luaran (outcome) yang diharapkan. Tindakan keperawatan adalah perilaku atau aktivitas spesifik yang dikerjakan oleh perawat untuk mengimplementasikan apa yang diintervensi oleh perawat (Tim Pokja SIKI DPP PPNI, 2017).

Menurut hasil penelitian Ruhman, (2017) adanya pengaruh pemberian relaksasi nafas dalam terhadap perubahan skala nyeri sebelum dan sesudah diberikan intervensi, yaitu pada kasus seorang pasien dilakukan intervensi selama 10- 15 menit, setelah itu peneliti meminta pasien istrahat sekitar 30-35 menit, selanjutnya peneliti mengkaji ulang nyeri dan hasilnya pasien mengatakan nyerinya berkurang dan hasil ini dibuktikan dengan observasi wajah pasien sudah lebih nyaman dan terasa rileks, pasien mengaatkan skala nyeri dari 6 (nyeri sedang) menurun menjadi 3 (nyeri ringan).

Berdasarkan asumsi peneliti bahwa intervensi yang dibuat apabila latihan diberikan secara berkala dan berkesinambungan diharapkan nyeri dapat berkurang. Pemberian latihan Teknik relaksasi nafas dalam pada masa ini sangat efektif karena masih dalam masa golden periode. Secara komprensif rencana keperawatan antara pasien 1 dan pasien 2 terdapat persamaan, dimana pasien 1 dan 2 nyeri yang dirasakan skala sedang. sehingga intervensi yang dibuat sama dan diharapkan dapat teratasi.

\section{Implementasi Keperawatan}

Implementasi

Keperawatan merupakan tahap ke empat dari proses keperawatan yang dimulai setelah perawat menyusun rencana keperawatan. Dengan rencana keperawatan yang dibuat berdasarkan diagnosis yang tepat, intervensi diharapkan dapat mencapai tujuan dan hasil yang diinginkan untuk mendukung dan meningkatkan status kesehatan klien (Budiono,2015). 
Implementasi keperawatan studi kasus yang diterapkan oleh peneliti yaitu melaksanakan asuhan keperawatan pada dua pasien dengan diagnosis medis Gastritis hanya berfokus pada satu masalah keperawatan yaitu masalah nyeri akut dan berfokus pada tindakan Teknik Relaksasi nafas dalam. Teknik Relaksasi nafas dalam ini meliputi Melatih pasien melakukan nafas dalam. Salah satu tanda dan gejala pada pasien gastritis yaitu nyeri di ulu hati menurut SDKI (2017) penatalaksanaan pasien gastritis mengajarkan cara teknik relaksasi nafas dalam dengan benar dan lakukan saat nyeri yang dirasakan timbul untuk meredakan dan menghilangkan nyeri.

Hasil penelitian implementasi yang telah di tetapkan untuk mengatasi masalah yang timbul atau terjadi pada saat dilakukan Teknik relaksasi nafas dalam. Dalam hal ini peneliti melakukan tindakan berupa: yaitu Nyeri akut berhubungan dengan agen pencendera fisiologis (inflamasi pada mukosa lambung), dalam upaya tersebut implementasi yang dilaksanakan meliputi: Mengidentifikasi lokasi, karakteristik, durasi, frekuensi, kualitas dan intensitas nyeri, mengidentifikasi skala nyeri, mengidentifikasi respon non verbal, memberikan Teknik non-farmakologi untuk mengurangi rasa nyeri yaitu melakukan Teknik relaksasi nafas dalam, menjelaskan penyebab, periode, dan pemicu nyeri, mengajarkan Teknik nonfarmakologi untuk mengurangi rasa nyeri yaitu dengan melakukan Teknik relaksasi nafas dalam, menganjurkan mengambil posisi nyaman, mendemonstrasikan dan latih teknik relaksasi, berkolaborasi dalam pemberian analgetic dan antasida yaitu : Ranitidin 2x1, Sucralfat Sirup 2x1 dan Omeprazole 2x $40 \mathrm{mg}$.

Hasil penelitian Widiatie, W. (2015). Hasil penelitian diperoleh teknik relaksasi nafas dalam mampu merangsang tubuh untuk melepaskan opoid endogen yaitu endorphin dan enkefalin.Hormon endorfin merupakan substansi sejenis morfin yang berfungsi sebagai penghambat transmisi impuls nyeri ke otak. Sehingga pada saat neuron nyeri perifer mengirimkan sinyal ke sinaps, terjadi sinapsis antara neuron perifer dan neuron yang menuju otak tempat seharusnya substansi akan menghasilkan impuls. Pada saat tersebut, endorfin akan memblokir lepasnya substansi dari neuron sensorik, sehingga sensasi nyeri menjadi berkurang

Berdasarkan asumsi peneliti bahwa pada proses implementasi asuhan keperawatan pada Tn.H dan Ny.S dengan Gastritis yang telah direncanakan sebelumnya. Terdapat persamaan hasil implementasi keperawatan dengan pemberian terapi farmakologi analgetik. Terapi farmakologi yang diberikan pada Tn.H dan Ny.S yaitu terapi analgetik Ranitidin 2x1, Sucralfat Sirup 2x1 dan Omeprazole 2x $40 \mathrm{mg}$. Terapi non farmakologi yang diberikan pada Tn.H dan Ny.S adalah terapi teknik relaksasi nafas dalam. Kesimpulan dan Analisa data yang didapat dari implementasi selama tiga hari. Kedua pasien mau dan mampu melakukan teknik relaksasi nafas dalam secara mandiri. Dan hasil yang didapat terapi relaksasi nafas dalam dapat menurunkan intensitas nyeri, dari skala sedang menjadi skala ringan.

\section{Evaluasi Keperwatan}

Evaluasi keperawatan adalah penilaian dengan cara membandingkan perubahan keadaan pasien (hasil yang diamati) dengan tujuan dan kriteria hasil yang dibuat pada tahap intervensi (Budiono, 2015).

Peneliti melaksanakan implementasi berdasarkan implementasi berdasarkan kriteria hasil yang telah di tetapkan. Dalam melaksanakan evaluasi, peneliti mengalami hambatan karena ada beberapa masalah yang belum teratasi. Hasil evaluasi dari diagnosis keperawatan nyeri akut berhubungan dengan agen pencendera fisiologis (inflamasi pada mukosa 
lambung) yang sudah dilakukan selama 3 hari didapatkan hasil evaluasi keperawatan sesudah penatalaksanaan teknik relaksasi nafas dalam pada Tn.H tanggal 18 Juni 2021 pukul 08.00 WIB pasien mengatakan nyeri yang dirasakan sudah tidak terasa lagi dan masalah keperawatanya teratasi. Sedangkan pada Ny.S tanggal 18 Juni 2021 pukul 09.00 WIB pasien mengatakan masih merasakan nyeri di ulu hati sedikit berkurang dengan skala nyeri 2 (sedang) dan masalah nyeri teratasi sebagian tindakan dilanjutkan oleh perawat diruangan.

Menurut penelitian Utami \& Kartika (2018) Bahwa terapi komplementer yang paling sering digunakan adalah relaksasi nafas dalam, karena relaksasi nafas dalam yang digunakan untuk proses terapi tersebut sangat membantu meringankan nyeri yang dialami pasien oleh karena itu memudahkan dalam proses penyembuhan dan dapat dilakukan secara mandiri oleh pasien.

Berdasarkan asumsi peneliti bahwa evaluasi keperawatan pada Kasus 1 (Tn.H) dan Kasus 2 (Ny.S) terdapat hasil evaluasi keperawatan Evaluasi secara komferensif dimana Tn.H dengan 3 masalah keperawatan yang seluruhnya dapat teratasi. Sedangkan pada Ny.S dengan 3 masalah keperawatan yang muncul hanya 2 masalah keperawatan yang teratasi dan 1 nya tidak teratasi. Dikarenakan nyeri yang dirasakan masih terasa tetapi sedikit berkurang dari skala 6 (sedang) menjadi skala nyeri 2 (ringan).

\section{KESIMPULAN}

Setelah dilakukan Asuhan Keperawatan Pada Pasien Tn. "H" dan Ny. "S" dengan Gastritis. Dengan menggunakan pendekatan proses keperawatan, maka di ambil kesimpulan dari tiap proses keperawatan yaitu :

1. Hasil dari pengkajian yang peneliti ditemukan Tn " $\mathrm{H}$ " dan Ny. A dengan
Gastritis di dapat data nyeri di daerah ulu hati skala nyeri 5 dan 6 RR : 22x/menit dan RR : 24x/menit, nafsu makan berkurang, mual dan muntah, pasien meringis, dan pasien memegangi area nyeri.

2. Diagnosis yang timbul Pada Tn "H" ada 3 diagnosa keperawatan : Nyeri akut berhubungan dengan agen pencendera fisiologis (inflamasi pada mukosa lambung), Gangguan Pola Tidur berhubungan dengan kurang Kontrol tidur (mengeluh sulit tidur karna nyeri), dan Defisit Nutrisi berhubungan dengan ketidakmampuan mencerna makanan. Sedangkan Diagnosis yang timbul Pada Ny "S" ada 3 diagnosa keperawatan : Nyeri akut berhubungan dengan agen pencendera fisiologis (inflamasi pada mukosa lambung), Termogulasi tidak efektif berhubungan dengan stimulasi pusat termogulasi (inflamasi) dan Defisit Nutrisi berhubungan dengan ketidakmampuan mencerna makanan.

3. Pada intervensi keperawatan pada pasien Tn " $\mathrm{H}$ " dan Ny "S" dengan diagnosis yang muncul yaitu Nyeri akut berhubungan dengan agen pencendera fisiologis (inflamasi pada mukosa lambung), Intervensi: identifikasi lokasi, karakteristik, durasi, freukensi, kualitas dan intensitas nyeri, identifikasi skala nyeri, identfikasi respon non verbal, berikan teknik non-farmakologi untuk mengurangi rasa nyeri yaitu teknik relaksasi nafas dalam, jelaskan penyebab, periode, dan pemicu nyeri, anjurkan mengambil posisi nyaman, demonstrasikan dan latih teknik relaksasi, dan kolaborasi pemberian analgetik.

4. Implementasi penerapan Teknik Relaksasi nafas dalam dengan nyeri Gastritis yaitu pada pasien Tn. "H" skala nyeri 5 (sedang) menjadi tidak nyeri lagi di hari ketiganya dan pasien Ny. "S" skala nyeri 6 (sedang) menjadi 2 (Ringan) di hari ketiganya. 
5. Evaluasi yang didapat pada pasien pertama Tn " $\mathrm{H}$ " didapatkan pasien tidak merasakan nyeri lagi, sebelum dilakukan Teknik relaksasi nafas dalam skala nyeri 5 (sedang), masalah nyeri teratasi, dan intervensi di hentikan. Untuk evaluasi yang didapat pasien kedua Ny "S" didapatkan skala 2 (Ringan), sebelum dilakukan Teknik relaksasi nafas dalam skala nyeri 6 (sedang), masalah nyeri teratasi Sebagian, dan intervensi dilanjutkan oleh perawat ruangan.

\section{SARAN}

Adapun saran yang dapat diberikan peneliti terkait dengan Asuhan Keperawatan ini adalah sebagai berikut :

\section{Bagi Peneliti}

Dapat dijadikan oleh peneliti sebagai salah satu referensi dan menambah ilmu pengetahuan, serta dapat dijadikan sebagai pedoman dalam pengembangan penerapan teknik relaksai nafas dalam pada pasien dewasa dengan Gastritis.

2. Bagi Rumah Sakit

Hasil penelitian ini dapat dijadikan sebagai bukti nyata akan efek penerapan prosedur teknik relaksasi nafas dalam meredakan nyeri sehingga dapat dijadikan sebagai suatu Standar Operasional Prosedur (SOP) atau Standar Asuhan Keperawatan (SAK) untuk meredakan nyeri pada pasien dewasa dengan Gastritis.

\section{Bagi Perkembangan Ilmu}

\section{Keperawatan}

Hasil penelitian ini dapat dijadikan masukan atau sumber informasi serta dasar pengetahuan bagi para mahasiswa-mahasiswi DIII Akademi Keperawatan dan dapat dijadikan sebagai materi latihan dalam meredakan nyeri pada pasien dewasa dengan Gastritis dengan penerapan teknik relaksasi nafas dalam.

\section{DAFTAR PUSTAKA}

Afdal Jayadi.(2018). Asuhan keperawatan Pada Pasien Gastritis Ny " $W$ " dalam Pemenuhan Kebutuhan Rasa Nyaman (Bebas Nyeri) Di Ruangan Laika Mendidoha RSUD

Bahteramas(KTI).Kendiri

(ID).Poltekkes Kemenkes Kendiri Jurusan Perawatan.

Amin Huda Nurarif \& Kusuma Hardhi. (2015). Aplikasi Asuhan Keperawatan Berdasarkan Diagnosa Medis dan Nanda NIC-NOC.Jakarta.EGC

Anggraini,A. (2015). Faktor-faktor Yang Berhubungan Dengan Kejadian Gastritis Di Puskesmas Rengat Kabupaten Indragiri Hulu (Skripsi).Pekanbaru (ID) : STIKes Payung Negeri Pekanbaru.

Angkow, Julia.(2016). "Faktor-faktor yang berhubungan dengan kejadian gastritis di Wilayah Kerja Puskesmas Bahu Kota Manado" (Jurnal).Manado : Keperawatan Fakultas Kedokteran Universitas Sam Ratulangi Manado.

Brunner \& Suddarth.(2012). Keperawatan Medikal Bedah.(edisi 8).Jakarta : EGC.

Budiono \& Pertami, Sumirah Budi.(2015).Konsep dasar keperawatan. Jakarta : Bumi Medika.

Dermawan dan Rahayuningsi. (2018). Keperawatan Medikal Bedah.Edisi 1.Gosyen Publishing..Yogyakarta

Dinkes Prov. SumSel.(2019). Profil Kesehatan Provinsi Sumatera Selatan. Pusat data dan Informasi Kesehatan : Palembang.

Dipiro JT, Wells BG, Schwinghammer TL, DiPiro, CV. (2016). Pharmacotherapy: 
Pathophysiological Approach 9th Edition. Mc Graw Hill Company Inc:New York.

Dodoi.(2018). Penerapan Teknik Relaksasi Nafas Dalam Untuk Penurunan Nyeri Pada Pasien Dengan Gastritis Du Puskesmas Petanang (KTI), LubukLinggau (ID) : Poltekkes Palembang.

H. Sahar, Riyani (2016).Efektivitas Relaksasi Benson dan Nafas Dalam Terhadap Perubahan Tingkat Kecemasan (Skripsi). Makassar (ID) : UIN Alauddin Makassar.

Huzaifah.(2017). "Hubungan Pengetahuan Tentang Penyebab Gastritis Dengan Perilaku Pencegahan".Vol. 1 No. 1 (Agustus,2017).Cipta : Jakarta

Indayani.(2018). "Pengaruh Pemberian Jus Buah Pepaya (Carica Papaya) Terhadap Tingkat Nyeri Kronis Pada Penderita Gastritis Di Wilayah Puskesmas Mungkid." STIKES PKU Muhammadiyah Surakarta: 353-65.

KemenKes RI.(2018). Profil Kesehatan Indonesia. Jakarta : Kementrian Kesehatan RI.

Kirnantoro, \& Maryana.(2019). Anatomi Fisiologi. Yogyakarta: Pustaka Baru Press. Sudoyo, Aru W, dkk. Buku Ajar Ilmu Penyakit Dalam. Jilid I Edisi VI. Jakarta: Interna Publishing; 2014.

LeMone, Burke, \& Bauldoff,(2016).Keperawatan Medikal Bedah, Alih bahasa. Jakarta: EGC.

Monika, T.(2018). "Hubungan antara Pengetahuan dan Tingkat Stres Terhadap Kekambuhan ulang gastritis Di Wilayah kerja Puskesmas Kota sungai Penuh Tahun 2018 ${ }^{e e}$. Mena\a Ilmu. Vol. XIII.
NANDA.(2015). buku diagnosa keperawatan definisi dan klasifikasi 2015-2017. Jakarta: EGC.

Novitayanti, Eka.(2020). "Identifikasi Kejadian Gastrritis Pada Siswa SMU Muhammadiyah 3 Masaran" INFOKES, Vol. 10 No. 1,Februari 2020: STIKes Mitra Husada Karanganyar.

Nurhanifah, D, Afni, A.R.N \& Rahmawati. (2018). "Pengaruh Guided Imaginary Terhadap Penurunan Nyeri Pada Klien Gastritis Di Wilayah Kerja Puskesmas Di Banjarmasin). Healthy Mu-Journal. 2(1): 24-30.

Putra, Galang D. E, Ayu Reni D. Firlyani, Muhammad F. Fauzan, Tazkiyah Annafisa, Nisma A. Bawazier, Ruswien N. Amine, Indri W. Wardani, Profnika Munasir, Devi Azura, Ayudika Permatasari, Fitri P.Sari.(2017). "Pengetahuan Mahasiswa Di SurabayaTerhadap Penggunaan Antasida”. Vol. 4 No. 2, (50-55).Jawa Timur : Fakultas Farmasi, Universitas Airlangga.

Putri, Rona Sari Mahaji.(2017). "Hubungan pola makan dengan timbulnya gastritis pada pasien di Universitas Muhammadiyah Malang Medical Centre (UMC)". Jurnal Keperawatan Universitas Tibhuwana Tunggadewi Malang.

Rejeki, Aulia Putri.(2019). “Gambaran Pengetahuan Pasien Tentang Penyebab Gastritis di Ruang Rindu A RSUP H Adam Malik Medan Tahun 2019”. Jurnal Keperawatan : Poltekkes Kemenkes Medan

$\begin{array}{ccr}\text { Rika.(2016). } & \text { Hubungan } & \text { Antara } \\ \text { Pengetahuan } & \text { Dan } & \text { Perilaku } \\ \text { Pencegahan } & \text { Gastritis } & \text { Pada }\end{array}$


Mahasiswa Jurusan Keperawatan (Skripsi). Makassar (ID) : UIN Allauddin Makassar.

Ruhman, M. (2017). "Analisis Praktik Klinik Keperawatan Pada Pasien Dispepsia Dengan Intervensi Relaksasi Nafas Dalam Dan Relaksasi Aromaterapi Bunga Mawar Terhadap Perubahan Skala Nyeri Di Ruang Unit Gawat Darurat Rsud Aji Muhammad. Karya Tulis Ilmiah. Program Studi Profesi Ners: STIKes Muhammadiyah Samarinda

Saydam. (2017). Penyakit Gastritis Dengan Gangguan Pencernaan. Bandung : Alfabeta. Diakses Pada Tanggal 27 Maret 2020.

Selviana, Berta, Yolanda. 2015."Effect Of Coffee And Stress With The Incidence Gastritis"e. J Majority Jurnal. Vol.4. No. 2.

Supetran, I. (2018). "Efektifitas Penggunaan Teknik Relaksasi Otot Progresif Dalam Menurunkan Tingkat Nyeri Pasien Gastritis Di Rumah Sakit Daerah Madani Palu.” PROMOTIF: Jurnal Kesehatan Masyarakat 6(1).

Susilowati, L, Hariri MH. 2019. "Hubungan Pola Makan Dengan Kejadian Gastritis Pada Pelajar $\mathrm{X}^{\mathrm{Ce}}$. Jurnal antar Keperawatan.

Syafi'i, Muhammad \& Dina Andriani. "Faktor-faktor Yang Berhubungan Dengan Kejadian Gastritis pada Pasien Yang Berobat Di Puskesmas". Jurnal Keperawatan dan Fisioterapi(JKF) Vol. 2 No. 1 Edisi Mei-Oktober 2019. Aceh : Sekolah Tinggi Ilmu Kesehatan Nurul Hasanah.

Sylvia, (2012). Buku Patologis : Penerbit buku Kedokteran : EGC
Utami \& Kartika (2018). “Terapi Komplementer Guna Menurunkan Nyeri Pasien Gastritis". Prodi Studi Pendidikan Ners STIKes Bukittinggi, Indonesia. Volume 1 No. 32018.

Tarwoto dan Wartonah.,2015. Kebutuhan Dasar Manusia dan Proses Keperawatan . Edisi :4 .Jakarta.

Tim Pokja SDKI DPP PPNI. (2017). Standar Diagnosis Keperawatan Indonesia Definisi dan Indikator Diagnostik. Jakarta: Dewan Pengurus PPNI.

Widiatie, W. (2015). Pengaruh Teknik relaksasi nafas dalam terhadap penurunan intensitas nyeri pada ibu postseksio sesarea di rumah sakit unipdu medika Jombang. Eduhealth, 5(2).

World Health Organization (WHO). (2018). Global Report on Gastritis. France. WHO. 